\title{
Education for Sustainable Development: The Role of Tertiary Institutions in Nigeria
}

\author{
Dr. Fatimah M. Palmer \\ Dept. Of Fine And Applied Arts, \\ University Of Benin, Edo State, Nigeria \\ Email: Fmpalmer2256@yahoo.com
}

\author{
Doi:10.5901/ajis.2013.v2n3p303
}

\begin{abstract}
The vision of education for sustainable development is "A world where everyone has the opportunity to benefit from quality education and learn the values, behavior and lifestyles required for a sustainable future for positive societal transformation". Tertiary institutions have a role to play in this regard. However, as stated by Scott \& Gough (2006), "It is not the job of the university to promote particular political orthodoxy (in the form of sustainable development for example); it is their job to educate students to examine critical policies, ideas, concepts and systems, then to make up their own mind". Tertiary institutions can also collaborate with communities to promote and sustain development. This paper looks at how tertiary institutions can be efficacious in promoting the values of sustainable development in Nigeria, and the possible challenges it is likely to encounter and recommendation made.
\end{abstract}

\section{Introduction}

Sustainable development is currently a widely used concept signaling that there is indeed need for a global change in thinking about the direction and nature of human development. This change in thinking may be considered one of the businesses of tertiary institutions of learning. As explained by Wals (2005:11), 'Education as an institution can be seen as a reflection of the society that supports it. Hence it is not surprising that some of society's ills can be found in our schools and tertiary institutions'. The schools and tertiary institutions are therefore the right place to start instilling behavioral changes for sustainable development.

Education for sustainable development is a dynamic concept that encompasses a new vision of education. An education (at all levels) that can shape the world of tomorrow, equipping individuals and societies with the skills, perspectives, knowledge and value to live and work in a sustainable manner. An education that seeks to balance human and economic well-being with cultural tradition and respect for the earth's natural resources should therefore be the focus of tertiary institutions for developing the required behavior towards sustainability.

In the pursuance of sustainable development through education, educators, learners and other stakeholders from the community need to reflect critically on their communities, identify non-viable elements in their lives, become empowered to develop and evaluate alternative strategies to collectively fulfill these visions.

\section{Support for Sustainability in Higher Education}

The $2^{\text {nd }}$ African Union Meeting on Experts on the Revitalization of Higher Education in Africa held in Accra (March, 2006) stressed the important role that Africa's tertiary institutions have in contributing to continental development. At the meeting, it was indicated that higher education institutions have a responsibility to develop ideas and knowledge for improving Africa's social and economic conditions in the sustainable development of Africa.

UNESCO and the Association for the development of Education in Africa have also re-emphasized the important role of higher education in contributing to Africa's sustainable development. Several declarations and partnerships have been formed to strengthen the focus on the major initiatives which highlights sustainable development, one of which is the United Nation's declaration of 2005-2014 as the decade of Education for sustainable development.

\section{Sustainable Development as a Learning Process}

By 1996, more than 300 definitions of 'sustainable development' had been published. This open-endedness is frustrating to some educators who feel that the need to know the boundaries of things and how one thing is different from another is 
important, if they are to teach well. But sustainable development is an open-ended process, a vision that society must work towards, which may manifest in different ways and in different contexts.

The term 'sustainability' is therefore often used, rather than sustainable development, in order to reflect a sense of process or movement. Scott and Gough (2003) propose that sustainability is 'a process through which we shall need to learn to live more in tune with the environment....sustainable development is a learning process through which we can, (if we choose) learn to build our capacity to live more sustainably'. In fact, they argue that the process of sustainable development is unlikely to take place without sustainable learning that is multi-sectoral, multi-leveled, multi-disciplinary and diverse.

The link between sustainable development and learning is very significant for the tertiary institution context. Learning how to learn in new and different ways is an important skill for both students and professionals: how to move from experiences, feeling and facts to understanding and action; how to ask the right questions about environment and development issues; to probe deeply "beneath the skin" of issues; where and how to look for relevant information; how to use ones existing knowledge and the insight of others to evaluate, analyze, interpret and critique information in order to make sense and meaning, and use ones new insights to make relevant decisions. These are some of the dimensions of "learning how to learn" which would be relevant in helping our society tackle environment and development issues in any context.

Sustainable development is a dynamic and evolving concept with many dimensions and interpretations, and because it is so open-ended, it can be interpreted in many different ways; the various interpretations often reflect not only contextual, but ideological differences. The main issue is, to use the idea of sustainable development to reflect on the nature of our world (including development and environmental issues, vulnerability and risk), on key emerging responses to what is wrong and how we should work towards improvement (sustainability) and the implications of this, for tertiary institutions.

There is also considerable value, particularly in the tertiary institution context in probing and reflecting on the different interpretations of sustainable development emerging in international forums, local and national governments, the corporate sector, education and other key players. There is the need to consider what interests these interpretations reflect, what the ethical and practical implications of following any one particular interpretation would be, and how these interpretations shape and influence the learning processes in the learning institutions and how this in turn will affect society.

As stated by the World Commission on Environmental and Development (1987), on sustainable development, "Humanity has the ability to make development sustainable to ensure that it meets the needs of the present without compromising the ability of future generations to meet their own needs".

\section{Education for Sustainable Development and Tertiary Institution}

Education for sustainable development is a $21^{\text {st }}$ century movement to revolutionize our education legacy. UNESCO, in considering the roles and functions of the tertiary institutions in promoting sustainable development stated that the following issues should be addressed particularly:

- Increasing the relevance of teaching and research for the societal process leading to more sustainable and discouraging unsustainable patterns of life

- Improving the quality and efficiency of teaching and research.

- Bridging the gap between science and education, and traditional knowledge and education.

- Strengthening interactions with actors outside the institution, in particularly local communities and businesses and

- Introducing decentralized and flexible management concepts.

UNESCO went on to say societal problems are ......"almost always complex problems that ask for multidisciplinary approaches. The challenge for tertiary institutions is to create rich learning environments that prepare learners for their roles in society. This implies that learning environments should;

- Offer access to scientific knowledge of good quality

- Enable students obtain the competencies needed to work together in multidisciplinary and multicultural teams, in a participatory process; and

- Bring the global dimension into individual learning environments.

Through the processes of education outreach and service to community and region, tertiary institutions constitute bridges between knowledge generation and the application of this knowledge to society. This bridging function is of great 
importance for innovation, development and creation of welfare.

Tertiary institutions have a challenge to be key role players in the process of life-long learning in society. It is their duty to innovate traditional learning environments and learning processes in such a way that they do not support the learning process of children and young adults in formal education only, but life-long learning, training and informal learning as well.

Tertiary institutions are not only about teaching, they are also society's powerhouse for research, thus researches conducted by faculty staff or students or collaborative teams should be community oriented for sustainable development to be felt and practiced by all.

\section{Teaching, Research and Community Engagement}

Tertiary institutions or higher education occupies an important position in shaping the way future generations learn to cope with the complexities of sustainable development. This is because; they form a link between knowledge generation and transfer to society, in the work they do to prepare future decision-makers. They also play an important role in generating new knowledge that shapes and influences the decision made by governments, industry and other stake holders, tertiary institutions also have a more direct role to play, in that they actively contribute to societal development through providing a service to society, and through more direct community engagement work.

Education for sustainable development innovations emphasizes the relationship between teaching, research and the broader community (made up of the environment, society, the economy and current and future generations). This community engagement is a very crucial dimension for ESD, as engagement with community raises sustainability questions, and helps tertiary institutions to 'situate' their contributions, and provides a forum for applied research , as well as offer opportunities for students to engage in service learning programmes which provide them with real-life experience. Community engagement also includes opportunities for working with business and industry to ensure sustainable production and consumption patterns and improved corporate governance. And lastly, it encourages tertiary institutions to review their relationship with the broader community, and their place and role within that community.

\section{Challenges}

Okorodudu-Fubara (2008) highlighted the following as major challenges to the success of ESD in higher education:

- Corporate governance

- Leadership

- Culture and work ethics

- Infrastructure

- Faculty and critical personnel

- Team building

- Academic freedom

- Strongholds and resistance to change

- Finances (funding)

- The triumvirate of access, quality and relevance.

She asserted that no matter how rotten a system is, there are always it's beneficiaries who will resist change. Other factors that may lead to resistance to change are:

- Lack of proper articulation of vision, thus the purpose of the change may not be understood.

- Wrong timing

- Inadequate ability to learn new skills

- Uncertainty on what role to play

- Inadequate training and education

- Fear of the unknown

- Lack of facilities to effect change etc.

Resistance to change may be in the form of uncooperative attitude, apathy, outright opposition, sabotage, amongst others. 


\section{Recommendation}

For tertiary institutions to effectively educate and instruct for sustainable development, all the key players, the students, the teachers, the community must be adequately involved and this can be achieved by:

- Provision of high quality education

- Effectively sensitizing all involved on the vision in education for sustainable development.

- Active participation and involvement of key players

- The tertiary institution must negotiate and agree on the major elements of change with the key players

- Exhibit positive attitude

- Encouragement of sustainable communication and showcase the advantages derivable from change

- Provide incentives and professional rewards

- Creative and pragmatic solutions to financial constraints

- Consultation and advocacy with community

- Capacity building and training

- Research and innovation

- Monitoring and evaluation

- Address local as well as global issues

\section{Conclusion}

Writers on the African Continent (Mamdani, 1994; Obong,2004; Makoni 2000) argue that tertiary institutions do not sufficiently equip students with the skills most needed in a complex, and rapidly changing world. Makoni (2000) for instance, argues that the goals of higher education is to develop skills for life-long learning, and notes that "...........it is the lecturer's and the tutor's responsibility to empower students to become active in their paths of discovery, both at the level of subject expertise and its application".

As lecturers, professors, managers and parents, we can either be overwhelmed or overcome by the rapid and complex nature of the changes in our societies, or we can take up the challenge to influence the direction of change.

Collaboratively and individually, education in higher institutions is not simply about knowledge transfer and skills enhancement, it is also about working with people to take charge of their own lives in a shared world. It is about emancipation and social relevance in its broadest sense.

\section{Reference}

African Union (2006). The 2nd AU meeting of experts on the revitalization of Higher education in Africa held in Accra March 2006.

Makoni, S. (2000). Improving teaching and learning in education: A handbook for Southern Africa. Johannesburg, Witwatersrand University Press.

Mamdani, M.(1994). Introduction. The quest for academic freedom. In Diouf, M. and Mamdani, M. (Eds) 1994. Academic Freedom in Africa. Dakar Senegal. CODESRIA.

Obong, Q. (2004). Academic dilemmas under neoliberal reforms: A review of Makerere University Uganda. In Zaleza, P.T. and Olukoshi, A. (Eds) 2004. African Universities in the 21st century. Vol. 1: Liberalisation and internationalization. Dakar, Senegal. Codesria.

Okorodudu-Fubara, M. T. (2008). Education for Sustainable Development in Higher Education: A convenient vision paper presented at the SIDA sponsored West and Central Africa Regional Training Workshop on ESD organized by OAU, lle-Ife in collaboration with Ramboll Natura AB,Sweden and Rhodes University, South Africa. 7-17 July 2008.

Scott, W. \& Gough, S. (2006). Universities and Sustainable Development in a Liberal Democracy: A reflection on the necessity for barriers to change. Technical Paper 3. Paris: UNESCO Educator Sector.

Scott, W. \& Gough, S. (2003). Sustainable Development and Learning: Framing the issues. London and New York. Routledge.

UNESCO. (2005). Education for Sustainable Development Information Brief Unesco.org/education/desd.

Wals, A. (Ed), (2005). Curriculum Innovations in Agriculture Education. The Hague. Elsevier Overheid.

World Commission On Environment and Development. (1987). Our Common Future. Oxford. Oxford University Press. 